\title{
AN ANALYSIS OF STUDENTS' ERRORS IN TRANSFORMING ACTIVE TO PASSIVE SENTENCE
}

\author{
Lina Septianasari \\ STKIP Muhammadiyah Bogor, Indonesia \\ Email: linasary62@yahoo.co.id
}

\begin{abstract}
Passive voice is one of the important English grammar that should be mastered because it is used at formal and informal communication. The EFL students tend to produce grammatical errors in transforming active to the passive sentence because of syntactical interference of their first language. The objectives of this research are to know the types of errors that students made in transforming active to passive sentences, to know the students' problems in transforming active to passive sentences and to know the proportion of the students' errors. The subject of this research is 20 English students at one private university in Lampung. The result of this research shows that the total number of errors that had been committed by the students based on surface strategy taxonomy is 280 errors, which falls into the following proportion of the four kinds of errors in surface strategy taxonomy: 126 errors of omission error, 18 errors of addition error, 120 errors of misformation error, and 16 errors of misordering error. Keywords: EFL, grammatical errors, passive voice.
\end{abstract}

Keywords: Students' error, active sentence, passive sentence

\section{INTRODUCTION}

English has a different syntactical form of passive voice compared with the same term in Indonesian language. Thus, foreign language learners in Indonesia got difficulties in changing the active sentence to passive sentence. In Bahasa Indonesia, the speakers have to change the object of the sentence to be the subject of the sentence, and then change the verb by adding prefix di- or ter-. Meanwhile, in English, the speakers should change the object of the active sentence to be the subject of the passive sentence. After that, the language users have to change the verb into past participle. The changing of the verb form and the usage of the past participle are the most difficult aspects that the students find in learning English passive voice. Therefore, students tend to make an error in constructing passive sentences.

Dulay, Burt, \& Krashen (1982) say that error is part of utterance or writing, which deviates from the standard norm of performance of the adult native speaker. The statement means that a grammatical error is a deviation which the students make in changing active sentences to passive sentences. In other words, the construction of the sentence is not in accordance with the standard grammar of English.

Several researches in error analysis have been discussed previously. Jabeen, Kazemian, \& Mustafai (2015) found out that, mostly, grammar errors produced by the students were caused by the interference of language one (L1). Those errors could be found in spoken or written utterances (Rini, 2014; Sari, 2018; Sermsook, Liamnimitr, \& Pochakorn, 2017).

At the beginning level, the students tend to have a lack of knowledge in grammar and they still frequently use their first language to communicate. The students do not master the grammar well, so they make some errors in transforming the sentence. The 
students commonly got difficulties to transform the form of a certain sentence to another form. Therefore, this research tried to identify and to classify the errors made by the participants in transforming active to the passive sentence. The researcher assumes that the research of error analysis is still needed in order to come closer to the problem faced by the teacher and then the teacher can choose the better or even the best method and technique of teaching to which they should focus on. In line with this statement, Hasyim (2002) argued that error analysis is needed for both teachers and learners as the reflection and evaluation during the learning process.

The objective of this research is to know the types of errors that the participants made in using passive voice. In brief, by analyzing the students' error, the researcher does hope that this research can improve the effectiveness of the learning process and get the solution on how to minimize the students' error.

Dealing with the learning process, it is very common for EFL students to make some errors in their utterance. Dulay et al. (1982) say that error is the part of utterance or writing, which deviates from the standard norm of performance of the adult native speaker. It somehow has a different structure with Standard English spoken by native speakers. Gorbet (1974) added that the teachers should be aware of the errors produced by the learners by providing an error correction strategy for their teaching and learning process.

EFL students mostly have some kind of errors in using English grammar since Bahasa Indonesia and English have different grammatical rules. Harmer (2007) said that grammar can thus be partly seen as knowledge of what words can go where and what form these words should take. Lacking knowledge in grammar becomes the main factor in making grammatical errors. Harmer (2007) states that error is a mistake that the students can't correct themselves. Meanwhile, Lengo (1995) mentioned that errors are believed to be an indicator of the learners' stages in their target language development.

Dulay et al. (1982) classify the types of error based on the surface strategy taxonomy into four classifications. They are omission error, addition error, misformation error, and misordering error. Richards (1971) pointed out 4 causes of developmental error, such as overgeneralization, ignorance of rule restrictions, incomplete application of rules, and false conception.

\section{METHOD}

The researcher uses a descriptive qualitative method in this research. The researcher conducts the research to the Fourth Semester Students of English Department in STKIP Muhammadiyah Bogor. The research had been conducted in March 2016. The researcher used purposive sampling to collect the data by taking 8 students as the sample. Bailey (1994) states, that in purposive sampling, the investigator does not necessarily have a quota to fill from within various strata, as in quota sampling. Rather, the researcher uses his or her own judgment about which respondents to choose and picks only those who best meet the purposes of the study.

In collecting the data, the researcher used triangulation. Moleong (2008) states that triangulation is a technique to check the data which uses the other things to compare the result of the interview toward the object of the research. The researcher used test items, interview techniques, and documentation as part of triangulation to get the data. The main instrument of this research is test items. The second instrument is an interview. Bailey (1994) states, that the interview is a special case of social interaction between two persons and as such is subject to some of the same rules and restrictions as other instances of social interaction. Interview is used to classify the stage of students' errors based on Developmental Category. The last instrument is documentation. Bailey (1994) states that 
document study shares with observation the advantage that spontaneous actions or feelings can be recorded when they occur, rather than at a time specified by the researcher. The documentation is collected during the researcher conduct the research.

The first step that the researcher did to gain the data was by giving the test items to the students. The researcher asked the students to transform 20 active sentences into passive sentences. After that, the researcher analyzed the data. Then, the researcher conducted an interview for the students to get information about their errors and their problems in transforming active to passive sentences. Documentation is used by the researcher to support the data and to avoid the data from the biases.

\section{FINDINGS AND DISCUSSION}

Surface Strategy Taxonomy is used to analyze the data of this research. Based on Surface Strategy Taxonomy, the researcher found 4 types of errors made by the students. They are omission, addition, misformation and misordering. The researcher has classified the students' errors based on the tenses that have been tested as presented in the table below. The table shows the classifications of the students' errors based on the tenses used in the passive voice.

Table 1. The classification of students' errors

\begin{tabular}{|c|c|c|c|c|}
\hline No. & Tenses & Sentence's Formula & Students answers & Correct answers \\
\hline 1. & Simple Present & $\begin{array}{l}\text { Active: } \\
\text { S+V }+\mathrm{V}_{1}+\mathrm{O} \\
\text { Passive: } \\
\text { O+to be+ }+\mathrm{V}_{3}+\text { by }+\mathrm{S}\end{array}$ & $\begin{array}{l}\text { Omission } \\
\text { 1. The floor is swept every day. } \\
\text { 2. The fairytale is told my } \\
\text { grandmother. } \\
\text { Misformation } \\
\text { 3. The floor is sweeped by the } \\
\text { servant. } \\
\text { Misordering } \\
\text { 4. The floor every day is swept } \\
\text { by the servant. }\end{array}$ & $\begin{array}{l}\text { 1. The floor is swept by } \\
\text { the servant every day. } \\
\text { 2. The fairytale is told by } \\
\text { my grandmother. } \\
\text { 3. The floor is swept by } \\
\text { the servant. } \\
\text { 4. The floor is swept by } \\
\text { the servant every day. }\end{array}$ \\
\hline 2. & Present Continuous & $\begin{array}{l}\text { Active: } \\
\text { S+TO BE+V-ing+O } \\
\text { Passive: } \\
\text { O+to be+being+ } \mathrm{V}_{3}+\text { by+S }\end{array}$ & $\begin{array}{l}\text { Omission } \\
\text { 5. Is your house painted by Mr. } \\
\text { Brown? } \\
\text { 6. Is your house being painted? } \\
\text { Misformation } \\
\text { 7. That report is being } \\
\text { preparing by Alex. }\end{array}$ & $\begin{array}{l}\text { 5. Is your house being } \\
\text { painted by Mr. Brown? } \\
\text { 6. Is your house being } \\
\text { painted by Mr. Brown? } \\
\text { 7. That report is being } \\
\text { prepared by Alex. }\end{array}$ \\
\hline 3. & Present Perfect & $\begin{array}{l}\text { Active: } \\
\text { S+HAS/HAVE }+\mathrm{V}_{3}+\mathrm{O} \\
\text { Passive: } \\
\mathrm{O}+\text { has/have }+ \text { been }+\mathrm{V}_{3}+ \\
\text { by }+\mathrm{S}\end{array}$ & $\begin{array}{l}\text { Omission } \\
\text { 8. The door has opened by } \\
\text { Tom. } \\
\text { 9. Has those papers signed by } \\
\text { Mr. Andrew? } \\
\text { Misformation }\end{array}$ & $\begin{array}{l}\text { 8. The door has been } \\
\text { opened by Tom. } \\
\text { 9. Has those papers been } \\
\text { signed by Mr. Andrew? } \\
\text { 10. Many bags have been } \\
\text { bought by her. }\end{array}$ \\
\hline
\end{tabular}


10. Many bags had bought by she.

\begin{tabular}{|c|c|c|c|c|}
\hline 4. & Simple Past & Active: & Omission & 11. I was examined by \\
\hline & & $\begin{array}{l}\mathrm{S}+\mathrm{V}_{2}+\mathrm{O} \\
\text { Passive: } \\
\mathrm{O}+\text { to be }+\mathrm{V}_{3}+\text { by }+\mathrm{S}\end{array}$ & $\begin{array}{l}\text { 11. I examined by lecturer } \\
\text { yesterday. } \\
\text { Misformation } \\
\text { 12. Me was examined by my } \\
\text { lecturer yesterday. }\end{array}$ & $\begin{array}{l}12 . I \text { was examined by my } \\
\text { lecturer yesterday. }\end{array}$ \\
\hline 5. & Past Continuous & $\begin{array}{l}\text { Active: } \\
\mathrm{S}+\text { to be }+\mathrm{V} \text {-ing }+\mathrm{O} \\
\text { Passive: } \\
\mathrm{O}+\text { to be }+ \text { being }+\mathrm{V}_{3}+\text { by } \\
+\mathrm{S}\end{array}$ & $\begin{array}{l}\text { Omission } \\
\text { 13. A letter was written by } \\
\text { Achmad. } \\
\text { Misformation } \\
\text { 14. A letter was write by } \\
\text { Achmad. }\end{array}$ & $\begin{array}{l}\text { 13. A letter was being } \\
\text { written by Achmad. } \\
\text { 14. A letter was being } \\
\text { written by Achmad. }\end{array}$ \\
\hline 6. & Past Perfect & $\begin{array}{l}\text { Active: } \\
\mathrm{S}+\text { had }+\mathrm{V}_{3}+\mathrm{O} \\
\text { Passive: } \\
\mathrm{O}+\text { had }+ \text { been }+\mathrm{V}_{3}+\text { by }+ \\
\mathrm{S}\end{array}$ & $\begin{array}{l}\text { Omission } \\
15 . \text { The book had returned by } \\
\text { Kathy to the library. } \\
\text { Misformation } \\
16 \text {. The book has been returned } \\
\text { by Kathy to the library. }\end{array}$ & $\begin{array}{l}\text { 15. The book had been } \\
\text { returned by Kathy to the } \\
\text { library. } \\
\text { 16. The book had been } \\
\text { returned by Kathy to the } \\
\text { library. }\end{array}$ \\
\hline 7. & Simple Future & $\begin{array}{l}\text { Active: } \\
\mathrm{S}+\text { will/shall }+\mathrm{V}_{-1}+\mathrm{O} \\
\text { Passive: } \\
\mathrm{O}+\text { will/shall + be }+\mathrm{V}_{3}+\text { by } \\
+\mathrm{S}\end{array}$ & $\begin{array}{l}\text { Omission } \\
\text { 17. My book will borrowed by } \\
\text { Jane. } \\
\text { Addition } \\
18 \text {. Ann is will be invited to the } \\
\text { party by Bill. }\end{array}$ & $\begin{array}{l}\text { 17. My book will be } \\
\text { borrowed by Jane. } \\
\text { 18. Ann will be invited to } \\
\text { the party by Bill. }\end{array}$ \\
\hline 8. & Future Perfect & $\begin{array}{l}\text { Active: } \\
\mathrm{S}+\text { will }+ \text { have }+\mathrm{V}_{-3}+\mathrm{O} \\
\text { Passive: } \\
\mathrm{O}+\text { will + have been }+\mathrm{V}_{-3}+ \\
\text { by }+\mathrm{S}\end{array}$ & $\begin{array}{l}\text { Omission } \\
\text { 19. The announcement will be } \\
\text { made by the president. } \\
\text { Misordering } \\
\text { 20. The announcement have } \\
\text { will made by the president. }\end{array}$ & $\begin{array}{l}\text { 19. The announcement } \\
\text { will have been made by } \\
\text { the President } \\
20 \text {. The announcement } \\
\text { will have been made by } \\
\text { the President }\end{array}$ \\
\hline
\end{tabular}


Based on the table above, it can be seen that the sample of this research did not master the tenses. Thus, they got difficulties when they should transform the sentences from active sentences to passive sentences. It indicated that the students need to expand their understanding of grammar.

After administering the interview, the students' errors in transforming active to passive voice were caused by some problems. First, the students lacked knowledge of tenses. They did not know clearly the basic formula of the tenses in an active sentence. Therefore, they did not know how to transform the active sentence into a passive sentence correctly. Second, the students could not decide which "to be" that should be used in transformation form. Third, the students had low vocabularies, as a result, they were not able to change the verb from present participle or participle into past participle correctly. In short, the students' knowledge about passive voice is still inadequate. Here are the total number of students' errors that have been found Omission 126 (45\%), Addition 18 (6\%), Misformation 120 (43\%), Misordering 16 (6\%).

It can be seen from the finding that the highest frequency of errors dealing with the transformation sentence from active to a passive sentence is omission which reaches almost half of the total number of errors is 126 or $45 \%$. The other types of error that students made mostly are misformation which is exactly 120 or $43 \%$. Addition takes the third position by accumulating 18 errors or about $6 \%$ of total errors. Finally, the lowest type of error is misordering in which about 16 errors or $6 \%$ of total errors. The explanation for each of the errors can be explained as follows:

\section{Omission Errors}

There are some phenomena of omission errors made by the sample, such as:

a. Omitting the past participle

This type of error is only made by a few students. The students omit the past participle in a passive sentence. It might have happened because the students have lack concentration when they did the test.

b. Omitting the word "by"

The students failed to add the word "by" in a passive sentence before the object pronoun. Some of them forgot to add the word "by", so they directly write or add the object pronoun after past participle. Some of them did not know how to determine which the passive that should use a by-phrase or not. Therefore, some of them omit the word "by" and the object pronoun.

c. Omitting the auxiliary verb "will" in the future perfect tense

The other case of omission in future perfect tense occurs in the use of "will". The data shows that the sample of this research missed putting the auxiliary verb when they transformed an active sentence into a passive sentence. As Indonesian language does not have the rule of tense like in English, this case may occur because the foreign language user needs to learn more or become more familiar with English grammar.

\section{d. Omitting the form of "to be"}

In this case, most of the students omit "to be" in a passive sentence. It is because they do not understand the formula of the passive sentences clearly. They thought that in transforming active to passive sentences, they only had to change the verb into past participle. 


\section{Addition Error}

In this type of error, the students use "to be "after the subject although there is another to be in the sentence. Thus, there is double "to be" in one sentence. Basically, the students still do not understand the use of to be for appropriate tense.

\section{Misformation Error}

There are four phenomena of misformation errors made by students, such as:

a. Misformation of "verb"

Misformation of the verb is made by the students because they failed to use the correct form of the verb for appropriate tense and subject. The students did not use appropriate "verb" although they have changed the sentences into passive sentences. Some of them still use the verb of the active sentence and some of them change the participle (V2) into a verb base (V1). They did not change it into past participle correctly. The students got the difficulties to change the first or the second verb form to the third verb form. It occurs because their first language (Bahasa Indonesia) does not have an irregular verb.

b. Misformation of "to be"

Misformation of "to be" is made by the students because they put incorrect copula which ungrammatically does not match the rule of English syntax. The students used the wrong form of "to be" for a plural and singular subject. The students also still have a similar problem in choosing the correct "to be" for particular tenses.

c. Misformation of Object Pronoun

In this type of error, the students did not change the subject pronoun to object pronoun. They still used the subject pronoun as the object pronoun.

d. Misformation of "auxiliary verb"

In this case, the students failed to use the correct auxiliary verb which appropriates with the tense. They have lack understanding about the form of tense (especially in perfect tense). Therefore, they got difficulties in transforming active to a passive sentence with the correct formula.

\section{Misordering Error}

Misordering error takes the least frequent of error. Generally, the students made errors because they failed to arrange the correct order of the sentence. The students did not place the correct order of the word after subject, verb, object pronoun, and so on when they transformed an active sentence into a passive sentence.

Related to the source of error stated by Corder (1981), the errors of the students can be classified into intralingual transfer since the students got some difficulties because of the rule of the target language itself. The students were confused to use the different rules for each pattern. The students used one rule for another rule which grammatically did not match. They used the same rule for the entire pattern. It seems that the students tend to make errors that are caused by the overgeneralization of the rule of the target language. In line with the previous statement, based on Brown's classification of error (Brown, 2000), these errors belong to intralingual transfer by considering that the errors were caused by the student's knowledge. The students had a lack of knowledge in grammar, so they tend to make some errors in transforming active sentences to the passive sentence. 
Based on the result and finding, it can be said that some of the problems were caused by the differences of grammatical rules between the students' first language and the language that has been learned. It is normal that the foreign language learner might find some different features in the target language which are difficult to understand. They might need a process and commit some errors at first in order to understand the language pattern. Dulay et al (1982:138) said that making an error is an inevitable part of learning and people cannot learn without first systematically committing an error. It can be said that the students cannot really learn in the class without knowing when an error is made by himself or somebody else.

In short, the students' error is so usual and normal. The students can learn from the errors that have been made by them. By these errors they made, the students are expected to make some improvements in the learning process. Furthermore, as the teacher, we should be able to handle these phenomena so we can increase the students' mastery in using English grammar.

\section{CONCLUSION}

Data taken in this research show that the sample of this research still deals with errors in transforming an active sentence into a passive sentence. It is known from the result of triangulation that the sample of this research made 4 types of error. They are omission, addition, misformation, and misordering. The students need to enhance their understanding of English syntax. They have to understand the pattern of the active sentence and passive sentence.

\section{REFERENCES}

Bailey, K. D. (1994). Methods of Social Research: Fourth Edition. New York: The Free Press.

Brown, H. D. (2000). Principles of Language Learning and Teaching. New Jersey: Prentice-Hall.

Dulay, C. H., Burt, M. K., \& Krashen, S. (1982). Language Two. Oxford: Oxford University Press.

Gorbet, F. (1974). Error Analysis: What Teachers Can Do. In R. In Shiu (Ed.), Errors: A New Perspective. Toronto: Research Division, Directorate of Studies, Civil Service Commision.

Harmer, J. (2007). The Practice of English Language Teaching. England: Longman.

Hasyim, S. (2002). Error Analysis in the Teaching of English. $K @ t a, 4(1), 42-50$.

Jabeen, A., Kazemian, B., \& Mustafai, M. S. (2015). The Role of Error Analysis in Teaching and Learning of Second and Foreign Language. Education and Linguistics Research, 1(2). https://doi.org/10.5296/elr.v1i1.8189

Lengo, N. (1995). What is An Error? Forum, 33(3), 20-24.

Moleong, R. J. (2008). Metodologi Penelitian Kualitatif. Bandung: Rosda.

Richards, J. C. (1971). A Non-Contrastive Approach. English Language Teaching, 25(3).

Rini, S. (2014). The Error Analysis on the Students of English Department Speaking Scripts. Register, 7(2).

Sari, R. A. (2018). Students' Grammatical Error Analysis in Speaking. Jurnal Pendidikan Dan Pengajaran, 5(2).

Sermsook, K., Liamnimitr, J., \& Pochakorn, R. (2017). An Analysis of Errors in Written English Sentences: A Case Study of Thai EFL Students. English Language Teaching, 10(3). https://doi.org/10.5539/elt.v10n3p101 